\title{
ATL54, a RING-H2 domain protein selected by a gene co- expression network analysis, is associated with secondary cell wall formation in Arabidopsis
}

\author{
Soichiro Noda ${ }^{1}$, Yoshinori Takahashi ${ }^{1}$, Yuta Tsurumaki ${ }^{1}$, Masaomi Yamamura ${ }^{1}$, \\ Nobuyuki Nishikubo ${ }^{2, a}$, Masatoshi Yamaguchi ${ }^{2,3, b}$, Nozomu Sakurai ${ }^{4}$, \\ Takefumi Hattori ${ }^{1, c}$, Hideyuki Suzuki ${ }^{4}$, Taku Demura ${ }^{2,3,5}$, Daisuke Shibata ${ }^{4}$, \\ Shiro Suzuki ${ }^{1}$, Toshiaki Umezawa ${ }^{1,6, *}$ \\ ${ }^{1}$ Research Institute for Sustainable Humanosphere, Kyoto University, Uji, Kyoto 611-0011, Japan; ${ }^{2}$ RIKEN Plant Science \\ Center, Yokohama, Kanagawa 230-0045, Japan; ${ }^{3}$ Graduate School of Biological Sciences, Nara Institute of Science and \\ Technology, Ikoma, Nara 630-0192, Japan; ${ }^{4}$ Kazusa DNA Research Institute, Kisarazu, Chiba 292-0818, Japan; ${ }^{5}$ RIKEN \\ Biomass Engineering Program, Yokohama, Kanagawa 230-0045, Japan; ${ }^{6}$ Institute of Sustainability Science, Kyoto University, \\ Uji, Kyoto 611-0011, Japan \\ *E-mail: tumezawa@rish.kyoto-u.ac.jp Tel: +81-774-38-3625 Fax: +81-774-38-3682
}

Received November 2, 2012; accepted March 4, 2013 (Edited by J. Yamaguchi)

\begin{abstract}
Biosynthesis of plant secondary cell walls is controlled by several master transcription factors. Ubiquitin ligases, which mediate ubiquitination of proteins, including transcription factors in the protein degradation pathway, are also believed to regulate secondary wall biosynthesis; however, the exact ubiquitin ligases involved in secondary wall formation have not yet been identified. We conducted a gene co-expression network analysis and found that ATL54, annotated as a RING-finger protein, was highly co-expressed with several transcription factor and enzyme genes involved in secondary wall formation. A recombinant ATL54 protein showed ubiquitin ligase activity. The expression of several biosynthetic genes of cellulose, lignin, and xylan in apical portions of inflorescence stems was up-regulated by ATL54 knock-out. The expression of Xylem Cysteine Peptidase1 (XCP1), which participates in the programmed cell death process of xylem tracheary elements, was down-regulated in middle stem portions of both ATL54-knock-out and ATL54-overexpressed mutants. Alteration of ATL54 expression levels did not, however, affect lignin and polysaccharide content and composition in whole mature stems. Our results suggest that ATL54 is an E3 ubiquitin ligase involved in secondary wall biosynthesis and programmed cell death during xylogenesis.
\end{abstract}

Key words: Arabidopsis thaliana, E3 ubiquitin ligase, gene co-expression network analysis, secondary cell wall formation.

In vascular plants, secondary cell walls exist in sclerenchymatous cells such as vessel elements, tracheids, and fibers. Secondary walls give these cells rigidity and confer water impermeability required for mechanical support and water transportation. Secondary cell walls are major components of wood, an essential feedstock for pulp and paper manufacturing, construction, and potential biofuel production. Understanding the mechanism of secondary cell wall formation would therefore not only shed light on metabolic events specific to vascular plants, but would also assist efforts to improve the utility of wood through biotechnological manipulation.

Recent progress on studies of transcription factors involved in secondary cell wall formation has revealed that a number of transcription factors play important roles. For example, in Arabidopsis, VASCULARRELATED NAC-DOMAIN6 (VND6) and VND7 regulate the development of metaxylem and protoxylem vessel elements, respectively (Kubo et al. 2005;

Abbreviations: 4CL, 4-coumarate CoA-ligase; ANAC, Arabidopsis NAC domain containing protein; ATL, Arabidopsis Tóxicos en Levadura; CCoAOMT, caffeoyl-CoA 3-O-methyltransferase; CesA, cellulose synthase; COR, correlation coefficient; F5H1, Ferulate 5-Hydroxylase1; FRA8, fragile fiber8; GUX2, glucuronic acid substitution of xylan2; HRP, horseradish peroxidase; IRX9, irregular xylem9; KNAT7, Knotted1-like homeodomain protein7; MBP, maltose binding protein; NST, NAC secondary wall thickening promoting factor; RAFL clones, RIKEN Arabidopsis full-length cDNA clones; RING, really interesting new gene; S/V ratio, syringaldehyde/vanillin ratio; SND, secondary wall-associated NAC domain; VND, vascular-related NAC domain; XCP1, xylem cysteine peptidase1; YFP, yellow fluorescent protein.

${ }^{a}$ Present address: Forest Technology Laboratories, Oji Paper Co., Ltd., Koto-ku, Tokyo 135-8558, Japan.

${ }^{b}$ Present address: Institute for Environmental Science and Technology, Saitama University, Saitama 338-0825, Japan.

c Present address: Institute of Socio-Arts and Sciences, The University of Tokushima, Tokushima 770-8502, Japan.

This article can be found at http://www.jspcmb.jp/

Published online May 24, 2013 
Yamaguchi et al. 2008), while NAC SECONDARY WALL THICKENING PROMOTING FACTOR1 (NST1) and NST3 [also called SECONDARY WALLASSOCIATED NAC DOMAIN PROTEIN1 (SND1) or ARABIDOPSIS NAC DOMAIN CONTAINING PROTEIN012 (ANAC012)] redundantly act as master switches that turn on secondary wall formation in fibers (Mitsuda et al. 2007; Zhong et al. 2006). MYB46 and MYB83 are direct downstream transcription factors of VND6, VND7, NST1, and NST3/SND1/ANAC012 (McCarthy et al. 2009; Ohashi-Ito et al. 2010; Yamaguchi et al. 2011). MYB46 and MYB83 can activate biosynthetic pathways for cellulose, xylan, and lignin, the three major secondary wall components (Ko et al. 2009; McCarthy et al. 2009; Nakano et al. 2010; Zhong et al. 2007). In contrast, MYB58 and MYB63 specifically activate lignin biosynthetic genes (Zhou et al. 2009). MYB58 and MYB63 expression is regulated by NST1, VND6, VND7, and MYB46, with the expression of MYB58 additionally regulated by NST3/SND1/ANAC012 (Zhou et al. 2009). In addition, several other NAC and MYB transcription factors regulated by NST3/SND1/ANAC012 have been found to affect secondary wall formation (Zhong et al. 2008). Among NST3-regulated transcription factors, MYB103 has been shown to be responsible for Ferulate 5-Hydroxylase1 (F5H1) expression and syringyl lignin biosynthesis (Öhman et al. 2012).

In addition to transcriptional regulation by transcription factors, it is presumed that protein degradation also plays a regulatory role in secondary wall formation, which is exemplified by the regulation of VND7 protein by proteasome-mediated degradation (Yamaguchi et al. 2008). Protein degradation via the ubiquitin-26S proteasome pathway is mediated by ubiquitination of target proteins (Moon et al. 2004). The process of ubiquitination requires three enzymes: a ubiquitin-activating enzyme (E1), a ubiquitinconjugating enzyme (E2), and a ubiquitin ligase (E3). E3 ubiquitin ligases are thought to determine the substrate specificity of ubiquitination. More than 1,300 members of E3 ligase families have been predicted in Arabidopsis (Mazzucotelli et al. 2006), but no E3 ligases related to secondary wall formation have yet been reported.

In this study, we conducted a gene co-expression network analysis and uncovered Arabidopsis Tóxicos en Levadura54 (ATL54, At1g72220), a putative ubiquitin ligase gene co-expressed with genes involved in secondary wall formation. We characterized ATL54 through a ubiquitination assay, a subcellular localization analysis, and analyses of transgenic plants in which ATL54 gene expression was up- or down-regulated.

\section{Materials and methods}

\section{Gene co-expression network analysis}

Gene co-expression data were obtained from the ATTED-II ver. c4.1 database (Obayashi et al. 2008), which includes expression data from 1,388 Arabidopsis thaliana samples derived from 58 experimental studies related to developmental stages and responses to biotic stress, abiotic stress, and hormones. A coexpression module was constructed using Microsoft Office PowerPoint 2007.

\section{Phylogenetic analysis}

The amino acid sequences of ATLs were obtained from The Arabidopsis Information Resource [TAIR; the Arabidopsis Biological Resource Center (ABRC), Ohio State University]. Alignment of the amino acid sequences and the construction of a phylogenetic tree by neighbor-joining method $(1,000$ bootstrap trials) were performed using ClustalX ver 2.0.11 (Larkin et al. 2007).

\section{Vector construction}

The open reading frame of the ATL54 gene was PCR-amplified from a RIKEN Arabidopsis full-length cDNA (RAFL) clone (RIKEN BioResource Center) and subcloned into a pENTR/ D-TOPO vector (Invitrogen Japan KK, Tokyo, Japan). The subcloned DNA was then transferred by recombination using LR Clonase II (Invitrogen) into several vectors: pH35GS for generation of overexpressors, $\mathrm{pH} 35 \mathrm{YG}$ and $\mathrm{pH} 35 \mathrm{GY}$ for a subcellular localization analysis (Kubo et al. 2005), and pMALDC-6myc for a ubiquitination assay (Zhang et al. 2005). The resulting plasmids were named pH35GS-ATL54, pH35YGATL54, pH35GY-ATL54, and pMAL-ATL54-6myc, respectively. For construction of a control vector for the subcellular localization analysis, the yellow fluorescent protein (YFP) gene cloned from $\mathrm{pH} 35 \mathrm{GY}$ was transferred into $\mathrm{pH} 35 \mathrm{GS}$ to obtain pH35GS-YFP. All constructs described above were verified by DNA sequencing. Primers used for vector construction and DNA sequencing are listed in online Supplemental Table S2.

\section{Plant materials and growth conditions}

Seeds of $A$. thaliana (ecotype Col-0) were sterilized with $70 \%$ ethanol and 2\% Plant Preservative Mixture (Plant Cell Technology Inc., Washington DC, USA). The seeds were then sown on germination medium (Kubo et al. 2005), vernalized at $4^{\circ} \mathrm{C}$ overnight, and incubated at $23^{\circ} \mathrm{C}$ under long-day conditions (16h light, $8 \mathrm{~h}$ dark). Two-week-old seedlings were transferred to Jiffy-7 peat plugs (Jiffy Products International AS, Stange, Norway) and grown at $23-25^{\circ} \mathrm{C}$ under longday conditions ( $16 \mathrm{~h}$ light, $8 \mathrm{~h}$ dark). A 1,000-fold dilution of Hyponex liquid concentrate (Hyponex Japan, Osaka, Japan) was given twice a month, and water was supplied twice weekly.

A. thaliana suspension-cultured T87 cells (Axelos et al. 1992) were obtained from RIKEN BioResource Center. T87 cells were maintained in mJPL3 medium (Ogawa et al. 2008) at $23^{\circ} \mathrm{C}$ under long-day conditions ( $16 \mathrm{~h}$ light, $8 \mathrm{~h}$ dark) with rotary 
shaking at $120 \mathrm{rpm}$.

\section{Plant transformation}

To obtain ATL54-overexpressed mutants, wild-type A. thaliana plants were transformed with pH35GS-ATL54 and selected according to the method described by Kubo et al. (2005).

\section{Screening for T-DNA insertional mutants}

T3 seeds of a T-DNA insertional mutant for ATL54 (SALK_072859; Alonso et al. 2003) were obtained from the Arabidopsis Biological Resource Center. The leaves of 10-dayold seedlings were immersed in PrepMan Ultra Sample Preparation Reagent (Applied Biosystems Japan Inc, Tokyo, Japan), and heated at $100^{\circ} \mathrm{C}$ for $10 \mathrm{~min}$ to extract genomic DNA. The supernatant containing the DNA was used as a template for PCR to select a homozygous mutant line (primers are listed in online Supplemental Table S2).

\section{Ubiquitination assay}

pMAL-ATL54-6myc was introduced into Escherichia coli strain BL21 Star (DE3) (Invitrogen) to produce a recombinant ATL54 protein fused with the maltose binding protein (MBP) at its $\mathrm{N}$-terminus and the $6 \times$ myc tag at its C-terminus. Growth of bacteria and induction of protein expression were performed according to the manufacturer's protocol. The bacteria were lysed by sonication in lysis buffer [ $20 \mathrm{mM}$ Tris- $\mathrm{HCl}$ ( $\mathrm{pH} 7.4)$, $150 \mathrm{mM} \mathrm{NaCl}, 2 \mathrm{mM} \mathrm{MgCl}_{2}, 10 \mathrm{mM} \beta$-mercaptoethanol, and Complete Protease Inhibitor Cocktail Tablets (Roche Diagnostics KK, Tokyo, Japan)], and centrifuged at $10,000 \times g$ for $10 \mathrm{~min}$ at $4^{\circ} \mathrm{C}$. The recombinant protein in the supernatant was purified using amylose resin (New England Biolabs Japan Inc, Tokyo, Japan) according to the manufacturer's protocol.

A ubiquitination assay using the recombinant protein (MBPATL54-6myc) was performed following the method of Zhang et al. (2005). Reaction products were separated by electrophoresis on a $5 \%$ polyacrylamide gel. Ubiquitin was detected by Western blotting using anti-ubiquitin antibodies [Ubiquitin (P4D1) Mouse mAb; Cell Signaling Technology Japan KK, Tokyo, Japan] and horseradish peroxidase (HRP)-labeled secondary antibodies (Anti-mouse IgG, HRP-linked Antibody; Cell Signaling Technology).

\section{Subcellular localization analysis}

Protoplast preparation and transformation was performed as described by Fujimoto et al. (2005) with modified concentrations of protoplasts and plasmids. The protoplast concentration was adjusted to $4 \times 10^{6}$ cells ml $^{-1}$ before transformation, and $15 \mu \mathrm{g}$ of $\mathrm{pH} 35 \mathrm{YG}-A T L 54, \mathrm{pH} 35 \mathrm{GY}-$ ATL54, or pH35GS-YFP was introduced. After transformation and washing, protoplasts were incubated at $23^{\circ} \mathrm{C}$ overnight in mJPL3 medium containing $0.4 \mathrm{M}$ mannitol and $0.4 \mathrm{M}$ glucose instead of sucrose. After incubation, protoplasts were examined under an epifluorescence microscope (BX51; Olympus Co, Tokyo, Japan) using a YFP filter set: a BP490-500HQ excitation filter, a DM505 dichroic mirror, and a BA515-560HQ emission filter.

\section{Quantitative RT-PCR analysis}

Approximately 20 -cm-high inflorescence stems of wild-type plants, ATL54-knocked-out mutants, and ATL54-overexpressed mutants (T3 homozygous lines transformed with pH35GSATL54) were harvested. After removal of flowers and peduncles, $3-\mathrm{cm}$ segments from the top of stems, middle of stems, and internodes just above the rosette leaves (hereafter referred to as the apical, middle, and basal portions, respectively) were cut off and immediately frozen in liquid nitrogen. Each sample was pulverized three times with zirconia beads ( $5 \mathrm{~mm}$ diameter) in 2-ml tubes using a TissueLyser (Qiagen KK, Tokyo, Japan) for $30 \mathrm{~s}$ at $25 \mathrm{~Hz}$. Total RNAs were isolated using an RNeasy Plant Mini Kit (Qiagen). RNAs extracted from three individuals of each line were combined and used as one sample. RNAs were treated with RQ1 RNase-Free DNase (Promega KK, Tokyo, Japan) to remove genomic DNA contamination, and reversetranscribed using SuperScript II Reverse Transcriptase (Invitrogen) to obtain first-strand cDNAs. Quantitative PCR was conducted on a 7300 Real Time PCR System (Applied Biosystems) using the cDNAs, gene-specific primers (listed in online Supplemental Table S2), and Power SYBR Green PCR Master Mix (Applied Biosystems) as previously described (Suzuki et al. 2006). A standard curve for each gene was prepared using a cDNA dilution series. The relative mRNA level of each sample was determined by Ct value using the standard curve, and normalized against ACTIN2 (At3g18780) mRNA levels to obtain the relative expression level.

\section{Chemical analyses of lignin and polysaccharides}

Mature (over 3 months old) inflorescence stems of wild-type plants, ATL54-knock-out mutants, and ATL54-overexpressed mutants were harvested. The stems were dried and powdered with stainless steel balls in stainless steel grinding jars using a TissueLyser for $2 \mathrm{~min}$ at $25 \mathrm{~Hz}$. The powdered samples were treated with an ethanol/toluene $(2: 1, \mathrm{v} / \mathrm{v})$ solution for $6 \mathrm{~h}$ and with methanol for $2 \mathrm{~h}$ using a Soxhlet apparatus. The residual powder was dried under high vacuum at room temperature to obtain organic solvent insoluble residues.

Lignin content in the residues was determined using the acetyl bromide method (Umezawa et al. 2007; Yamamura et al. 2011). A microscale nitrobenzene oxidation experiment (Yamamura et al. 2010) was performed for determination of relative amounts of guaiacyl and syringyl units in lignin.

Starch in the organic solvent insoluble residues was removed using an amylase treatment (Hattori et al. 2012), and the residues were subjected to sulfuric acid hydrolysis and alditol acetate derivatization (Hoebler et al. 1989). The carbohydrate content of the sulfuric acid hydrolysate was determined by the phenol-sulfuric acid method using 5\% phenol aqueous solution (Dubois et al. 1956). Alditol acetates were analyzed by gas chromatography-mass spectrometry on a GCMS-2010 Plus system (Shimadzu, Kyoto, Japan) under the following conditions: electron impact mode (70V); column, Supelco SP- 
$2330(30 \mathrm{~m} \times 0.25 \mathrm{~mm})$; initial temperature $170^{\circ} \mathrm{C}$ for $2 \mathrm{~min}$, then increased to $235^{\circ} \mathrm{C}$ by $4^{\circ} \mathrm{Cmin}^{-1}$; carrier gas, He; splitless injection.

\section{Results}

\section{Gene co-expression network analysis}

To find a ubiquitin ligase involved in secondary wall formation, we conducted a gene co-expression network analysis using the ATTED-II database. We first investigated genes co-expressed with transcription factor and enzyme genes involved in secondary wall formation. Among E3 ubiquitin ligase families, RING (Really Interesting New Gene)-finger proteins are the most frequent catalytic subunits of E3 ligases in Arabidopsis (Mazzucotelli et al. 2006). We therefore looked for genes annotated as "zinc finger (C3HC4-type RING finger) family protein" in the co-expressed gene list and found that At1g72220 (ATL54), At2g20650, At1g72200 (ATL11), and At3g10910 (ATL72) appeared frequently (Supplemental Table S1). Among these genes, ATL54 showed the highest correlation coefficients (CORs) for several transcription factor genes such as MYB58 (Atlg16490) $\quad(\mathrm{COR}=0.67), \quad$ NST3/SND1/ANAC012 (Atlg32770) $(\mathrm{COR}=0.68)$, and Knotted1-like Homeodomain Protein7 (KNAT7, At1g62990; Zhong et al. 2008) $(\mathrm{COR}=0.65)$. Xylan biosynthetic genes, including GlucUronic Acid Substitution of Xylan2 (GUX2, At4g33330; Mortimer et al. 2010) $(\mathrm{COR}=0.71)$ and Irregular Xylem9 (IRX9, At2g37090; Lee et al. 2007) $(\mathrm{COR}=0.69)$, were also highly co-expressed with ATL54. ATL11 showed modest CORs for KNAT7 $(\mathrm{COR}=0.56)$, IRX9 $(\mathrm{COR}=0.55)$ and another xylan biosynthetic gene Fragile Fiber8 (FRA8)/IRX7 (At2g28110; Peña et al. 2007) $(\mathrm{COR}=0.61)$. ATL72 showed a modest COR for FRA8/ IRX7 $(\mathrm{COR}=0.62)$. Because of the highest CORs for several secondary wall-associated genes, we focused on ATL54 in further analyses.

We then conducted a reciprocal search for coexpressed genes in the ATL54 co-expression network and created a co-expression module (Figure 1). In this module, several genes were highly co-expressed with ATL54: Caffeoyl-CoA 3-O-MethylTransferase7 (CCoAOMT7, At4g26220) encoding a putative CCoAOMT potentially involved in lignin biosynthesis (Raes et al. 2003), Lateral Organ Boundaries Domain30 (LBD30, also called Asymmetric Leaves2-like19 (ASL19) or Jagged Lateral Organ (JLO), At4g00220) $(\mathrm{COR}=0.65)$ encoding a transcription factor regulating tracheary element differentiation (Soyano et al. 2008), and At2g47670 $(\mathrm{COR}=0.67)$ encoding an invertase/pectin methylesterase inhibitor superfamily protein (Raiola et al. 2004; Scognamiglio et al. 2003). Several signalingrelated genes, such as Rho GTPase-activating Protein5

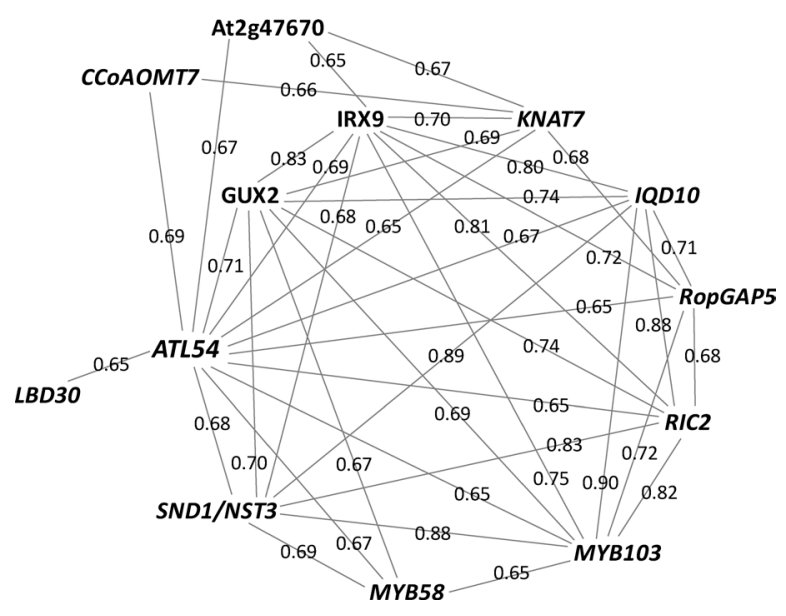

Figure 1. Co-expression relationship between ATL54 and other genes. A co-expressed pair of genes is connected with a line, with the correlation coefficient (COR) between them on the line. Only annotated genes for which CORs with ATL54 are greater than 0.64 are shown.

(RopGAP5, Atlg08340; Wu et al. 2000) $(\mathrm{COR}=0.65)$, Rop-interactive CRIB motif-containing Protein2 (RIC2, Atlg27380; Wu et al. 2001) $(\mathrm{COR}=0.65)$, and IQDomain10 (IQD10, At3g15150; Abel et al. 2005) $(\mathrm{COR}=$ 0.67), also showed relatively high CORs for ATL54.

\section{In silico and biochemical analysis of ATL54}

Alignment of amino acid sequences of ATL54 and several ATLs showed that ATL54 has typical characteristics of ATL proteins; ATL54 contains a RING-H2 domain, one hydrophobic region near the N-terminus, and a conserved motif named GLD (Supplemental Figure S1). Our phylogenetic analysis showed that ATL54 was far from both ATL11 and ATL72 and close to ATL55/RING1 (At5g10380; Lin et al. 2008) (Supplemental Figure S2). However, ATL54 and ATL55/RING1 shared only 23\% identity and 43\% similarity (see Supplemental Figure S1).

A RING-H2 domain is a type of RING domain frequently found in Arabidopsis (Kosarev et al. 2002). It has been shown that a RING domain protein alone can promote E1- and E2-dependent polyubiquitin chain formation, often referred to as auto-ubiquitination (Joazeiro et al. 1999; Leverson et al. 2000). We conducted an auto-ubiquitination assay to test ubiquitin ligase activity of ATL54. A recombinant ATL54 protein was expressed in E. coli and purified. The protein (MBPATL54-6myc) was then subjected to a ubiquitination reaction, and the reaction products were analyzed by Western blotting. Ubiquitinated proteins were detected in the presence of ubiquitin, ATP, E1 (UBE1), E2 (UbcH5b), and MBP-ATL54-6myc (Figure 2). When the reaction mixture did not contain E1, E2, or MBP-ATL54$6 \mathrm{myc}$, ubiquitinated proteins were not detected (Figure 2). These results indicate that MBP-ATL54-6myc can function as an E3 ubiquitin ligase. 


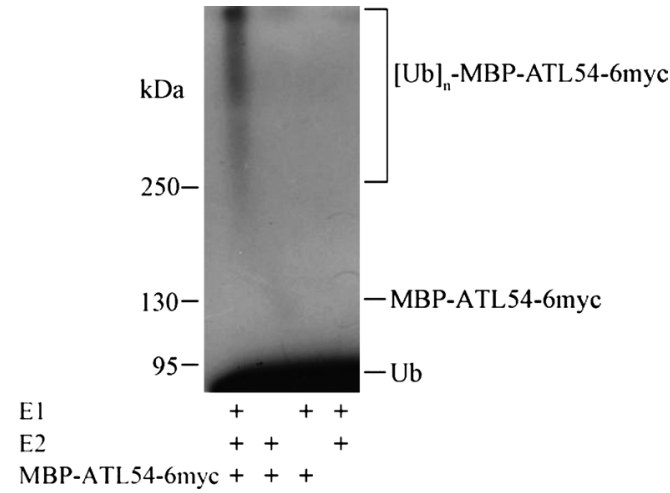

Figure 2. Auto-ubiquitination assay of a recombinant ATL54 protein. The recombinant MBP-ATL54-6myc protein was mixed with rabbit E1, human E2 (UbcH5b), ubiquitin, and ATP, and incubated at $30^{\circ} \mathrm{C}$ for $2 \mathrm{~h}$. The reaction products were subjected to a Western blot analysis using anti-ubiquitin antibodies. Ub, ubiquitin; $[\mathrm{Ub}]_{\mathrm{n}}$, polyubiquitin chain.

\section{Subcellular localization of ATL54}

The ATL54 sequence was analyzed using the TMHMM 2.0 program (http://www.cbs.dtu.dk/services/ TMHMM-2.0/), which predicted with high probability that amino acid residues 82-104 of ATL54 correspond to a transmembrane region (Figure $3 \mathrm{~A}$ ), suggesting that ATL54 is a membrane protein. To determine subcellular localization of ATL54, YFP-tagged ATL54 or YFP alone was transiently expressed in protoplasts of A. thaliana T87 suspension-cultured cells. When only YFP was expressed, its signal was distributed throughout the cytoplasm and the nucleus (Figure 3B). When the $\mathrm{N}$-terminus of ATL54 was fused with YFP, results were similar to that of YFP alone (Figure 3C). In contrast, when the C-terminus of ATL54 was tagged with YFP, the YFP signal was detected on plasma membranes (Figure 3D).

\section{Effect of ATL54 knock-out and overexpression}

To investigate whether ATL54 is involved in secondary wall biosynthesis, we examined mutants with altered ATL54 expression. We prepared a homozygous T-DNAtagged line of ATL54 (SALK_072859) as an ATL54knock-out mutant (Figure 4B). Transgenic plants overexpressing ATL54 were generated by Agrobacteriummediated transformation. When these plants were grown under long-day conditions, there was no apparent difference in stem growth among wild-type plants and ATL54-knock-out and ATL54-overexpressed mutants.

According to the Arabidopsis eFP browser (Winter et al. 2007), ATL54 is highly expressed at the base of inflorescence stems. We therefore used inflorescence stems for a gene expression analysis. We obtained $3-\mathrm{cm}$ segments from the apical, middle, and basal portions of 20 -cm-high inflorescence stems, and subjected them to quantitative RT-PCR. The correct transcripts of ATL54 were not detected in the ATL54-knock-out mutants

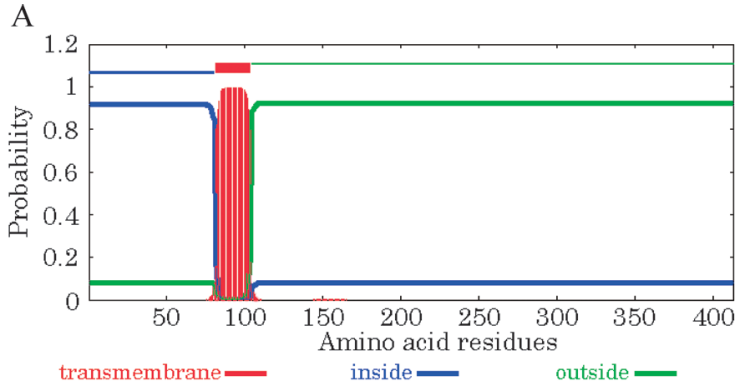

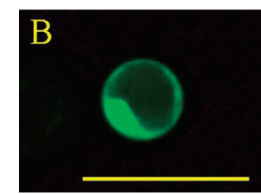

YFP

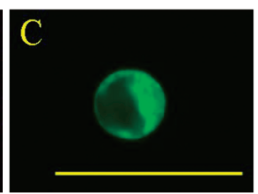

YFP-ATL54

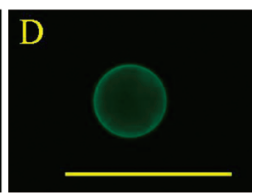

ATL54-YFP
Figure 3. Subcellular localization of the YFP-fused ATL54 protein. (A) A diagram of a transmembrane region predicted by the TMHMM 2.0 program. (B-D) Fluorescent images of transformed protoplasts. A. thaliana T87 cells in which YFP (B), ATL54 with its N-terminus YFP-tagged (C), or ATL54 with its C-terminus YFP-tagged (D) was expressed were detected under an epifluorescence microscope. Bars $=100 \mu \mathrm{m}$.

(Figure 4C), and ATL54 expression was increased in three lines of ATL54-overexpressed mutants, i.e., OX1, OX9, and OX10 (Figure 4D). Because the OX1 line showed the highest increase in ATL54 expression in all the three stem portions (Figure 4D), we used this line for further analyses.

Expression of secondary wall-specific cellulose synthase genes Cellulose Synthase8 (CesA8)/IRX1 (At4g18780), CesA7/IRX3 (At5g17420), and CesA4/IRX5 (At5g44030) (Taylor et al. 2003), and xylan biosynthetic genes IRX9, GUX1 (At3g18660), and GUX2 (Lee et al. 2007, Lee et al. 2012; Mortimer et al. 2010; Peña et al. 2007) was elevated two- to four-fold in apical stem portions of the ATL54-knock-out mutants (Figure 4E). Expression of a xylan biosynthetic gene IRX14 (At4g36890; Brown et al. 2007) and a lignin biosynthetic gene CCoAOMT1 (At4g34050; Do et al. 2007) was also up-regulated. The expression level of another lignin biosynthetic gene, 4-coumarate CoAligase1 (4CL1, At1g51680; Ehlting et al. 1999; Lee et al. 1995), was not changed significantly, and expression of a programmed cell death-associated gene, Xylem Cysteine Peptidase1 (XCP1; Funk et al. 2002; Zhao et al. 2000), was not affected. On the other hand, in middle stem portions, tested secondary wall biosynthetic genes were virtually unchanged by ATL54 knock-out and ATL54 overexpression, whereas XCP1 expression was significantly repressed in both mutants (Figure $4 \mathrm{~F}$ ). There were no significant gene expression changes in basal stem portions of either mutant (Figure $4 \mathrm{G}$ ).

To investigate whether alteration of ATL54 expression affects cell wall composition, we performed chemical 
A

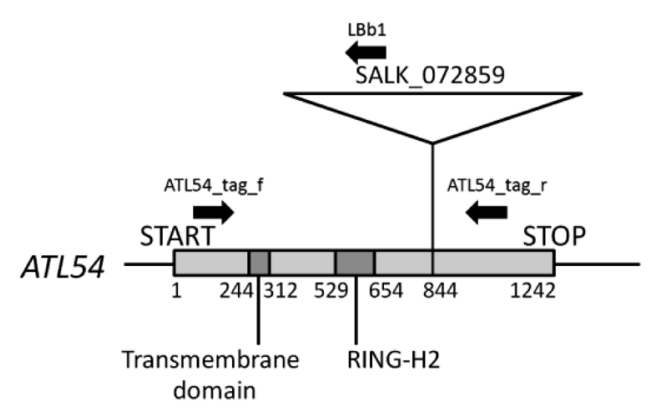

$\mathrm{D}$

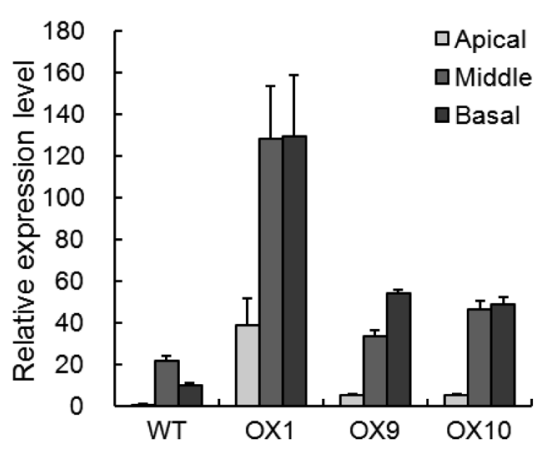

F

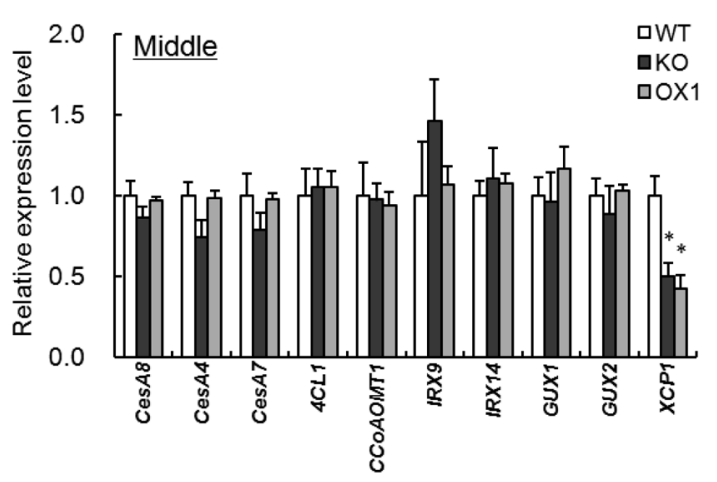

B

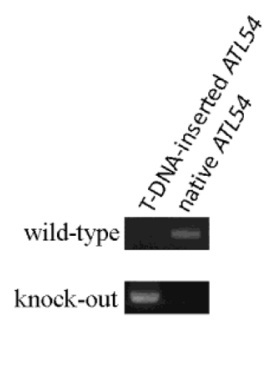

C

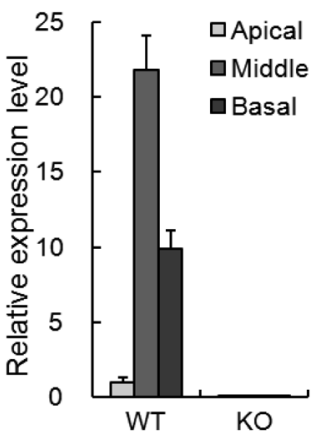

$\mathrm{E}$

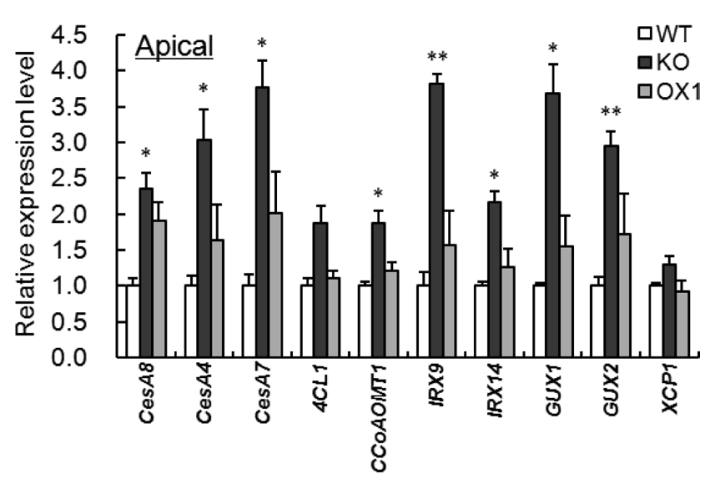

G

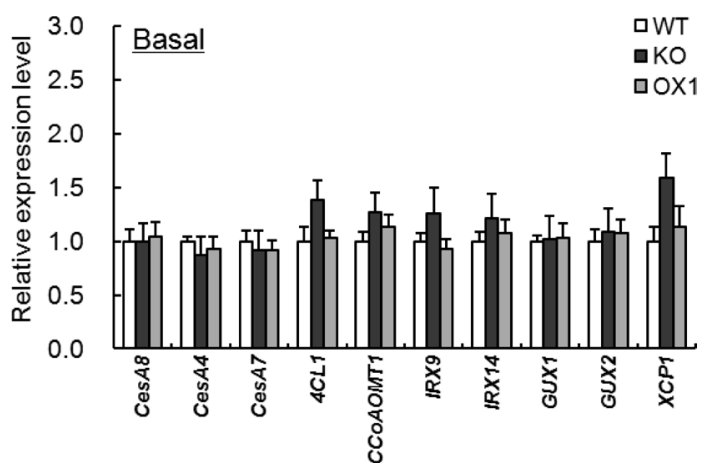

Figure 4. Effect of ATL54 knock-out and ATL54 overexpression on expression levels of secondary wall- and programmed cell death-related genes. (A) Schematic diagram of the T-DNA insertion site (SALK_072859) in the ATL54-knock-out mutant. The box represents the coding region. Arrowheads indicate annealing sites of primers used in confirmation of the insert (see Supplemental Table S2). (B) Results of PCR from genomic DNA. The T-DNA-inserted sequence was amplified from the genomic DNA of ATL54-knock-out mutants, whereas the native ATL54 was not amplified, confirming that the knock-out line was homozygous. (C-D) ATL54 expression level. Expression level of ATL54 in the apical, middle and basal stem portions of wild-type (WT), ATL54-knock-out (KO), and ATL54-overexpressed (OX) plants was measured by quantitative RTPCR. Three lines of the overexpressors (OX1, OX9, and OX10) were examined. The expression level in the apical portions of stems of the wild-type plants is set to 1. (E-G) Relative gene expression levels in apical (E), middle (F), and basal (G) stem portions. Expression levels of genes involved in biosynthesis of cellulose (CesA8, CesA4, and CesA7), lignin (4CL1 and CCoAOMT1), and xylan (IRX9, IRX14, GUX1, and GUX2), and a gene involved in programmed cell death (XCP1) were measured. Among the overexpressors, only OX1 is shown in (E-G) (see Results). Gene expression levels in wild-type plants are set to 1 . Error bars indicate standard errors $(\mathrm{n}=3)$. Asterisks indicate statistically significant differences $(* p<0.05 ; * * p<0.01)$ from the expression levels of wild-type plants.

analyses of organic solvent insoluble residues from whole mature stems of the ATL54-knock-out and ATL54overexpressed mutants. No drastic changes in lignin content and syringyl/guaiacyl ratio were observed in either (Supplemental Figure S3A, B). Furthermore, total carbohydrate content and neutral sugar composition were not statistically different between wild-type and mutant plants (Supplemental Figure S4A, B).

\section{Discussion}

Gene co-expression network analyses have been successfully used to identify novel genes participating in a particular metabolism (e.g., Ozaki et al. 2010). 
Consequently, we employed a gene co-expression network analysis to look for a ubiquitin ligase gene involved in secondary wall formation. We found that ATL54 was co-expressed with several genes involved in secondary wall formation with high correlation coefficients (Supplemental Table S1) and that the genes formed a co-expression module (Figure 1). ATL11 and ATL72 were also co-expressed with several secondary wall-associated genes with weaker correlation (Supplemental Table S1). A phylogenetic analysis showed that ATL54, ATL11, and ATL72 belong to distinct clades in the phylogenetic tree of ATLs (Supplemental Figure S2). This result is consistent with the classification of ATLs by Aguilar-Hernández et al. (2011), where ATL54, ATL11, and ATL72 were classified into distinct groups. ATL55, which is also named RING1 and triggers fungal toxin-induced programmed cell death (Lin et al. 2008), is the most similar protein to ATL54 (Aguilar-Hernández et al. 2011; Serrano et al. 2006). However, ATL55 and ATL54 share only $23 \%$ identity and $43 \%$ similarity (Supplemental Figure S1).

In our experiment using YFP-fused proteins, the fluorescence of N-terminus-tagged ATL54 was observed in cytoplasm and nuclei, whereas the fluorescence of C-terminus-tagged ATL54 was localized on plasma membranes. In the case of N-terminus-tagged ATL54, YFP might be released from YFP-tagged ATL54 by the cleavage of the N-terminus of ATL54. Another possible explanation is that anchorage of $\mathrm{N}$-terminus YFP-tagged ATL54 to plasma membranes might be interrupted by YFP, resulting in its incorrect localization.

We demonstrated that the recombinant ATL54 protein catalyzed E1- and E2-dependent auto-ubiquitination (Figure 2), indicating that ATL54 is an E3 ubiquitin ligase. The best characterized function of E3 ubiquitin ligases is labeling of target proteins for degradation via the ubiquitin-26S proteasome pathway. ATL31, an ATL family member, was recently shown to regulate response to the carbohydrate-nitrogen ratio via 14-3-3 protein degradation (Sato et al. 2009; Sato et al. 2011). ATL54 may also target such regulatory proteins.

Gene expression analysis of the mutants revealed that knock-out of ATL54 activated expression of three cellulose biosynthetic genes, four xylan biosynthetic genes, and one lignin biosynthetic gene in apical portions of stems (Figure 4E). These genes are all associated with secondary wall biosynthesis (Do et al. 2007; Mortimer et al. 2010; Peña et al. 2007; Taylor et al. 2003). Our results thus indicate that ATL54 affects the expression of a number of secondary wall biosynthetic genes in elongating portions of stems. On the other hand, in middle stem portions, ATL54 knockout and overexpression repressed expression of XCP1, a gene involved in programmed cell death in tracheary elements (Funk et al. 2002). ATL54 may have a role in the regulation of programmed cell death as well as secondary wall biosynthesis during xylogenesis.

Overexpression of ATL54 did not affect the expression of secondary wall biosynthetic genes in any tested inflorescence stem portions (Figure $4 \mathrm{E}-\mathrm{G}$ ). One possible reason for this result is that accumulation of the target protein of ATL54 might not be significantly affected by ATL54 overexpression. Knock-out of ATL54 also did not change expression of secondary wall biosynthetic genes in middle and basal stem portions (Figure 4F, G). These results might explain why quantity and composition of cell wall polysaccharides and lignin in whole mature stems were not substantially altered by either knockout or overexpression of ATL54 (Supplemental Figure S3, 4). The fact that knock-out of ATL54 did not affect secondary wall biosynthesis in middle and basal stem portions suggests that functionally redundant proteins of ATL54 are present.

In conclusion, we found that ATL54 is co-expressed with secondary wall-associated genes. We demonstrated that ATL54 has E3 ubiquitin ligase activity and appears to be involved in secondary wall formation and programmed cell death in inflorescence stems. The target of ATL54, necessary for understanding detailed function of ATL54, remains to be elucidated.

\section{Acknowledgements}

We thank Ms. Midori Koda for technical assistance with lignin content determination. We also thank the Arabidopsis Biological Resource Center (ABRC) at Ohio State University for providing seeds of ATL54-knock-out mutants, and the RIKEN BioResource Center for providing RAFL clones and Arabidopsis T87 suspensioncultured cells. The pMAL-DC-6myc vector was provided by Dr. Nam-Hai Chua, Rockefeller University. Portions of this study were conducted using the Development and Assessment of Sustainable Humanosphere/Forest Biomass Analytical System (DASH/FBAS) at the Research Institute for Sustainable Humanosphere, Kyoto University, Japan. This work was partly supported by Grants-in-Aid for Young Scientists (B) (No. 22780161) and for Scientific Research (B) (No. 20380102) from the Japan Society for the Promotion of Science (JSPS); the Ministry of Education, Culture, Sports, Science and Technology of Japan (MEXT) Special Coordination Funds for Promoting Science and Technology: Integrated Research System for Sustainability Science (IR3S); and a grant from the New Energy and Industrial Technology Development Organization (Development of Fundamental Technologies for Controlling the Process of Material Production of Plants).

\section{References}

Abel S, Savchenko T, Levy M (2005) Genome-wide comparative analysis of the IQD gene families in Arabidopsis thaliana and Oryza sativa. BMC Evol Biol 5: 72

Aguilar-Hernández V, Aguilar-Henonin L, Guzmán P (2011) Diversity in the architecture of ATLs, a family of plant ubiquitinligases, leads to recognition and targeting of substrates in different cellular environments. PLoS ONE 6: e23934

Alonso JM, Stepanova AN, Leisse TJ, Kim CJ, Chen H, Shinn P, 
Stevenson DK, Zimmerman J, Barajas P, Cheuk R, et al. (2003) Genome-wide insertional mutagenesis of Arabidopsis thaliana. Science 301: 653-657

Axelos M, Curie C, Mazzolini L, Bardet C, Lescure B (1992) A protocol for transient gene expression in Arabidopsis thaliana protoplasts isolated from cell suspension culture. Plant Physiol Biochem 30: 123-128

Brown DM, Goubet F, Wong VW, Goodacre R, Stephens E, Dupree P, Turner SR (2007) Comparison of five xylan synthesis mutants reveals new insight into the mechanisms of xylan synthesis. Plant J 52: 1154-1168

Do CT, Pollet B, Thévenin J, Sibout R, Denoue D, Barrière Y, Lapierre C, Jouanin L (2007) Both caffeoyl Coenzyme A 3-Omethyltransferase 1 and caffeic acid $O$-methyltransferase 1 are involved in redundant functions for lignin, flavonoids and sinapoyl malate biosynthesis in Arabidopsis. Planta 226: 1117-1129

Dubois M, Gilles KA, Hamilton JK, Rebers PA, Smith F (1956) Colorimetric method for determination of sugars and related substances. Anal Chem 28: 350-356

Ehlting J, Büttner D, Wang Q, Douglas CJ, Somssich IE, Kombrink E (1999) Three 4-coumarate:coenzyme A ligases in Arabidopsis thaliana represent two evolutionarily divergent classes in angiosperms. Plant J 19: 9-20

Fujimoto S, Yonemura M, Matsunaga S, Nakagawa T, Uchiyama S, Fukui K (2005) Characterization and dynamic analysis of Arabidopsis condensin subunits, AtCAP-H and AtCAP-H2. Planta 222: 293-300

Funk V, Kositsup B, Zhao C, Beers EP (2002) The Arabidopsis xylem peptidase XCP1 is a tracheary element vacuolar protein that may be a papain ortholog. Plant Physiol 128: 84-94

Hattori T, Murakami S, Mukai M, Yamada T, Hirochika H, Ike M, Tokuyasu K, Suzuki S, Sakamoto M, Umezawa T (2012) Rapid analysis of transgenic rice straw using near-infrared spectroscopy. Plant Biotechnol 29: 359-366

Hoebler C, Barry JL, David A, Delort-Laval J (1989) Rapid acid hydrolysis of plant cell wall polysaccharides and simplified quantitative determination of their neutral monosaccharides by gas-liquid chromatography. J Agric Food Chem 37: 360-367

Joazeiro CAP, Wing SS, Huang HK, Leverson JD, Hunter T, Liu YC (1999) The tyrosine kinase negative regulator $\mathrm{c}-\mathrm{Cbl}$ as a RING-type, E2-dependent ubiquitin-protein ligase. Science 286: 309-312

Ko JH, Kim WC, Han KH (2009) Ectopic expression of MYB46 identifies transcriptional regulatory genes involved in secondary wall biosynthesis in Arabidopsis. Plant J 60: 649-665

Kosarev P, Mayer KFX, Hardtke CS (2002) Evaluation and classification of RING-finger domains encoded by the Arabidopsis genome. Genome Biol 3: research0016.1-0016.12

Kubo M, Udagawa M, Nishikubo N, Horiguchi G, Yamaguchi M, Ito J, Mimura T, Fukuda H, Demura T (2005) Transcription switches for protoxylem and metaxylem vessel formation. Genes Dev 19: 1855-1860

Larkin MA, Blackshields G, Brown NP, Chenna R, McGettigan PA, McWilliam H, Valentin F, Wallace IM, Wilm A, Lopez R, et al. (2007) Clustal W and Clustal X version 2.0. Bioinformatics 23: 2947-2948

Lee C, O’Neill MA, Tsumuraya Y, Darvill AG, Ye ZH (2007) The irregular xylem 9 mutant is deficient in xylan xylosyltransferase activity. Plant Cell Physiol 48: 1624-1634

Lee C, Teng Q, Zhong R, Ye ZH (2012) Arabidopsis GUX proteins are glucuronyltransferases responsible for the addition of glucuronic acid side chains onto xylan. Plant Cell Physiol 53: 1204-1216

Lee D, Ellard M, Wanner LA, Davis KR, Douglas CJ (1995) The Arabidopsis thaliana 4-coumarate: CoA ligase (4CL) gene: stress and developmentally regulated expression and nucleotide sequence of its cDNA. Plant Mol Biol 28: 871-884

Leverson JD, Joazeiro CAP, Page AM, Huang Hk, Hieter P, Hunter T (2000) The APC11 RING-H2 finger mediates E2-dependent ubiquitination. Mol Biol Cell 11: 2315-2325

Lin SS, Martin R, Mongrand S, Vandenabeele S, Chen KC, Jang IC, Chua NH (2008) RING1 E3 ligase localizes to plasma membrane lipid rafts to trigger FB1-induced programmed cell death in Arabidopsis. Plant J 56: 550-561

Mazzucotelli E, Belloni S, Marone D, De Leonardis AM, Guerra D, Di Fonzo N, Cattivelli L, Mastrangelo AM (2006) The E3 ubiquitin ligase gene family in plants: regulation by degradation. Curr Genomics 7: 509-522

McCarthy RL, Zhong R, Ye ZH (2009) MYB83 is a direct target of SND1 and acts redundantly with MYB46 in the regulation of secondary cell wall biosynthesis in Arabidopsis. Plant Cell Physiol 50: 1950-1964

Mitsuda N, Iwase A, Yamamoto H, Yoshida M, Seki M, Shinozaki K, Ohme-Takagi M (2007) NAC transcription factors, NST1 and NST3, are key regulators of the formation of secondary walls in woody tissues of Arabidopsis. Plant Cell 19: 270-280

Moon J, Parry G, Estelle M (2004) The ubiquitin-proteasome pathway and plant development. Plant Cell 16: 3181-3195

Mortimer JC, Miles GP, Brown DM, Zhang Z, Segura MP, Weimar T, Yu X, Seffen KA, Stephens E, Turner SR, et al. (2010) Absence of branches from xylan in Arabidopsis gux mutants reveals potential for simplification of lignocellulosic biomass. Proc Natl Acad Sci USA 107: 17409-17414

Nakano Y, Nishikubo N, Goue N, Ohtani M, Yamaguchi M, Katayama Y, Demura T (2010) MYB transcription factors orchestrating the developmental program of xylem vessels in Arabidopsis roots. Plant Biotechnol 27: 267-272

Obayashi T, Hayashi S, Saeki M, Ohta H, Kinoshita K (2009) ATTED-II provides coexpressed gene networks for Arabidopsis. Nucleic Acids Res 37: D987-D991

Ogawa Y, Dansako T, Yano K, Sakurai N, Suzuki H, Aoki K, Noji M, Saito K, Shibata D (2008) Efficient and high-throughput vector construction and Agrobacterium-mediated transformation of Arabidopsis thaliana suspension-cultured cells for functional genomics. Plant Cell Physiol 49: 242-250

Ohashi-Ito K, Oda Y, Fukuda H (2010) Arabidopsis VASCULARRELATED NAC-DOMAIN6 directly regulates the genes that govern programmed cell death and secondary wall formation during xylem differentiation. Plant Cell 22: 3461-3473

Öhman D, Demedts B, Kumar M, Gerber L, Gorzsás A, Goeminne G, Hedenström M, Ellis B, Boerjan W, Sundberg B (2012) MYB103 is required for FERULATE-5-HYDROXYLASE expression and syringyl lignin biosynthesis in Arabidopsis stems. Plant J 73: 63-76

Ozaki S, Ogata Y, Suda K, Kurabayashi A, Suzuki T, Yamamoto N, Iijima Y, Tsugane T, Fujii T, Konishi C, et al. (2010) Coexpression analysis of tomato genes and experimental verification of coordinated expression of genes found in a functionally enriched coexpression module. DNA Res 17: 105-116

Peña MJ, Zhong R, Zhou GK, Richardson EA, O'Neill MA, Darvill AG, York WS, Ye ZH (2007) Arabidopsis irregular xylem 8 and irregular xylem 9 : implications for the complexity of glucuronoxylan biosynthesis. Plant Cell 19: 549-563 
Raes J, Rohde A, Christensen JH, Van de Peer Y, Boerjan W (2003) Genome-wide characterization of the lignification toolbox in Arabidopsis. Plant Physiol 133: 1051-1071

Raiola A, Camardella L, Giovane A, Mattei B, De Lorenzo G, Cervone F, Bellincampi D (2004) Two Arabidopsis thaliana genes encode functional pectin methylesterase inhibitors. FEBS Lett 557: 199-203

Sato T, Maekawa S, Yasuda S, Domeki Y, Sueyoshi K, Fujiwara M, Fukao Y, Goto DB, Yamaguchi J (2011) Identification of 14-3-3 proteins as a target of ATL31 ubiquitin ligase, a regulator of the $\mathrm{C} / \mathrm{N}$ response in Arabidopsis. Plant J 68: 137-146

Sato T, Maekawa S, Yasuda S, Sonoda Y, Katoh E, Ichikawa T, Nakazawa M, Seki M, Shinozaki K, Matsui M, et al. (2009) CNI1/ATL31, a RING-type ubiquitin ligase that functions in the carbon/nitrogen response for growth phase transition in Arabidopsis seedlings. Plant J 60: 852-864

Scognamiglio MA, Ciardiello MA, Tamburrini M, Carratore V, Rausch T, Camardella L (2003) The plant invertase inhibitor shares structural properties and disulfide bridges arrangement with the pectin methylesterase inhibitor. J Protein Chem 22: 363-369

Serrano M, Parra S, Alcaraz LD, Guzmán P (2006) The ATL gene family from Arabidopsis thaliana and Oryza sativa comprises a large number of putative ubiquitin ligases of the RING-H2 type. J Mol Evol 62: 434-445

Soyano T, Thitamadee S, Machida Y, Chua NH (2008) ASYMMETRIC LEAVES2-LIKE19/LATERAL ORGAN BOUNDARIES DOMAIN30 and ASL20/LBD18 regulate tracheary element differentiation in Arabidopsis. Plant Cell 20: 3359-3373

Suzuki S, Li L, Sun YH, Chiang VL (2006) The cellulose synthase gene superfamily and biochemical functions of xylem-specific cellulose synthase-like genes in Populus trichocarpa. Plant Physiol 142: 1233-1245

Taylor NG, Howells RM, Huttly AK, Vickers K, Turner SR (2003) Interactions among three distinct CesA proteins essential for cellulose synthesis. Proc Natl Acad Sci USA 100: 1450-1455

Umezawa T, Wada S, Yamamura M, Sakakibara N, Nakatsubo T, Suzuki S, Hattori T, Koda M (2007) Protocols for lignin analysis for Forest Biomass Analytical System of RISH, Kyoto University. Res Sustainable Humanosphere (Seizonkenkenkyu) 3: 73-75 (in Japanese)

Winter D, Vinegar B, Nahal H, Ammar R, Wilson GV, Provart NJ (2007) An "electronic Fluorescent Pictograph" browser for exploring and analyzing large-scale biological data sets. PLoS
ONE 2: e718

Wu G, Gu Y, Li S, Yang Z (2001) A genome-wide analysis of Arabidopsis Rop-interactive CRIB motif-containing proteins that act as Rop GTPase targets. Plant Cell 13: 2841-2856

Wu G, Li H, Yang Z (2000) Arabidopsis RopGAPs are a novel family of Rho GTPase-activating proteins that require the Cdc42/Rac-interactive binding motif for Rop-specific GTPase stimulation. Plant Physiol 124: 1625-1636

Yamaguchi M, Kubo M, Fukuda H, Demura T (2008) VASCULARRELATED NAC-DOMAIN7 is involved in the differentiation of all types of xylem vessels in Arabidopsis roots and shoots. Plant $J$ 55: 652-664

Yamaguchi M, Mitsuda N, Ohtani M, Ohme-Takagi M, Kato K, Demura T (2011) VASCULAR-RELATED NAC-DOMAIN7 directly regulates the expression of a broad range of genes for xylem vessel formation. Plant J 66: 579-590

Yamamura M, Hattori T, Suzuki S, Shibata D, Umezawa T (2010) Microscale alkaline nitrobenzene oxidation method for highthroughput determination of lignin aromatic components. Plant Biotechnol 27: 305-310

Yamamura M, Wada S, Sakakibara N, Nakatsubo T, Suzuki S, Hattori T, Takeda M, Sakurai N, Suzuki H, Shibata D, Umezawa $\mathrm{T}$ (2011) Occurrence of guaiacyl/p-hydroxyphenyl lignin in Arabidopsis thaliana T87 cells. Plant Biotechnol 28: 1-8

Zhang X, Garreton V, Chua NH (2005) The AIP2 E3 ligase acts as a novel negative regulator of ABA signaling by promoting ABI3 degradation. Genes Dev 19: 1532-1543

Zhao C, Johnson BJ, Kositsup B, Beers EP (2000) Exploiting secondary growth in Arabidopsis. Construction of xylem and bark cDNA libraries and cloning of three xylem endopeptidases. Plant Physiol 123: 1185-1196

Zhong R, Demura T, Ye ZH (2006) SND1, a NAC domain transcription factor, is a key regulator of secondary wall synthesis in fibers of Arabidopsis. Plant Cell 18: 3158-3170

Zhong R, Lee C, Zhou J, McCarthy RL, Ye ZH (2008) A battery of transcription factors involved in the regulation of secondary cell wall biosynthesis in Arabidopsis. Plant Cell 20: 2763-2782

Zhong R, Richardson EA, Ye ZH (2007) The MYB46 transcription factor is a direct target of SND1 and regulates secondary wall biosynthesis in Arabidopsis. Plant Cell 19: 2776-2792

Zhou J, Lee C, Zhong R, Ye ZH (2009) MYB58 and MYB63 are transcriptional activators of the lignin biosynthetic pathway during secondary cell wall formation in Arabidopsis. Plant Cell 21: $248-266$ 


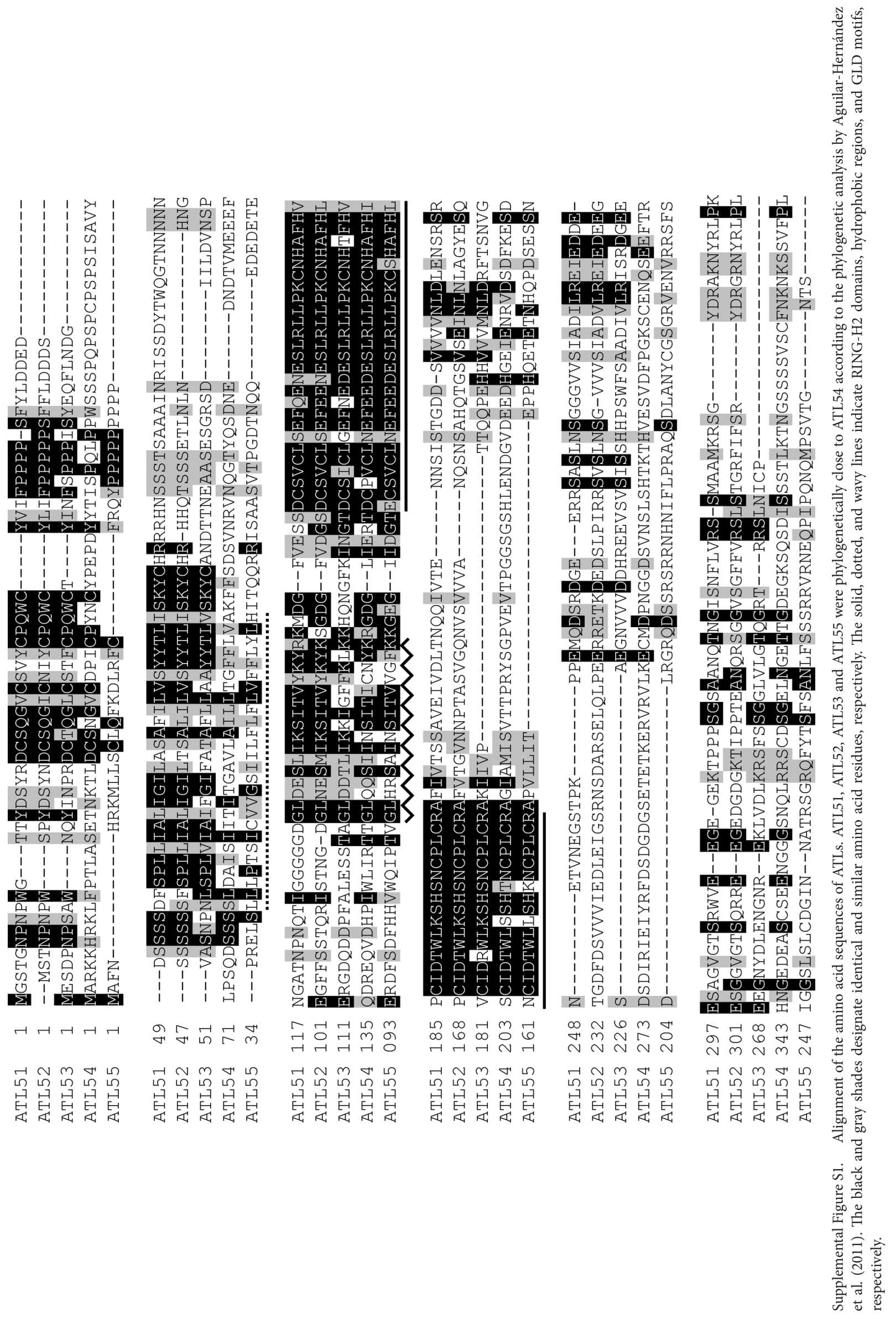


A

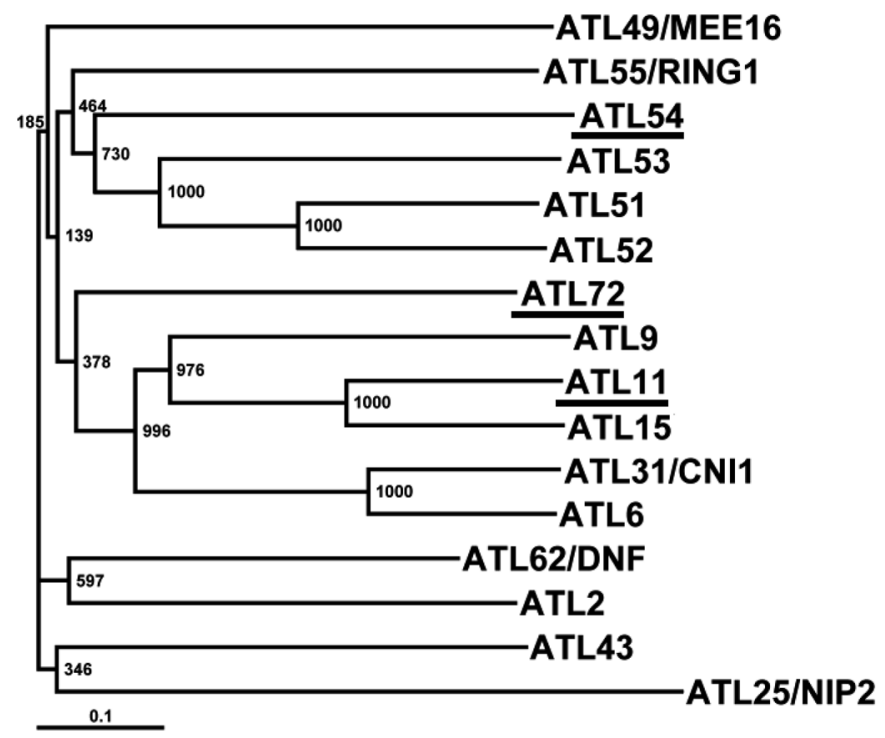

B

\begin{tabular}{|l|l|l|l|}
\hline Name & $\begin{array}{l}\text { Corresponding } \\
\text { gene ID }\end{array}$ & Function & Reference \\
\hline \hline ATL2 & At3g16720 & early elicitor response & Salinas-Mondragón et al. (1999) Plant Mol Biol 40: 579-590 \\
\hline ATL6 & At3g05200 & $\begin{array}{l}\text { carbon/nitrogen response } \\
\text { defense response }\end{array}$ & $\begin{array}{l}\text { Sato et al. (2009) Plant J 60: 852-864 } \\
\text { Maekawa et al. (2012) Plant Mol Biol 79: 217-227 }\end{array}$ \\
\hline ATL9 & At2g35000 & chitin-induced defense response & Berrocal-Lobo et al. (2010) PLoS ONE 5: e14426 \\
\hline ATL11 & At1g72200 & (unknown) & - \\
\hline ATL15 & At1g22500 & ascorbic acid response & Gao et al. (2011) J Exp Bot 62: 3647-3657 \\
\hline ATL25/NIP2 & At2g17730 & fixing RPOTmp on thylakoid membrane & Azevedo et al. (2008) Proc Natl Acad Sci USA 105: 9123-9128 \\
\hline ATL31/CN11 & At5g27420 & $\begin{array}{l}\text { carbon/nitrogen response } \\
\text { defense response }\end{array}$ & $\begin{array}{l}\text { Sato et al. (2009) Plant J 60: 852-864 } \\
\text { Maekawa et al. (2012) Plant Mol Biol 79: 217-227 }\end{array}$ \\
\hline ATL43 & At5g05810 & abscisic acid response & Serrano et al. (2006) J Mol Biol 62: 434-445 \\
\hline ATL49/MEE16 & At2g18650 & embryo development & Pagnussat et al. (2005) Development 132: 603-614 \\
\hline ATL51 & At3g03550 & (unknown) & - \\
\hline ATL52 & At5g17600 & (unknown) & - \\
\hline ATL53 & At4g17905 & (unknown) & - \\
\hline ATL54 & At1g72220 & (investigated in this study) & - \\
\hline ATL55/RING1 & At5g10380 & fungal toxin-induced programmed cell death & Lin et al. (2008) Plant J 56: 550-561 \\
\hline ATL62/DNF & At3g19140 & photoperiodic response & Morris et al. (2010) Plant Cell 22: 1118-1128 \\
\hline ATL72 & At3g10910 & (unknown) & - \\
\hline
\end{tabular}

Supplemental Figure S2. Phylogeny of ATL proteins. (A) Phylogenetic tree of previously reported ATLs and the ATLs remarked in this study. The tree was constructed by the neighbor-joining method with a bootstrap of 1,000 replicates. Bootstrap values are indicated near nodes. ATLs found by the gene co-expression network analysis were underlined. (B) Description of ATLs shown in (A). 
A

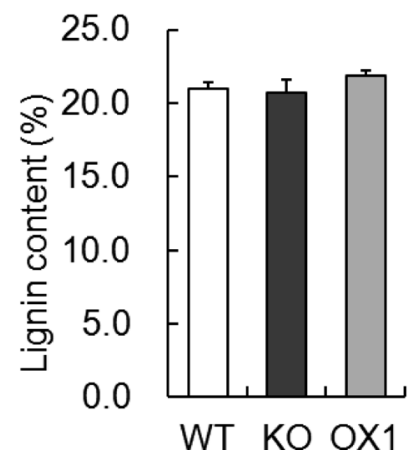

B

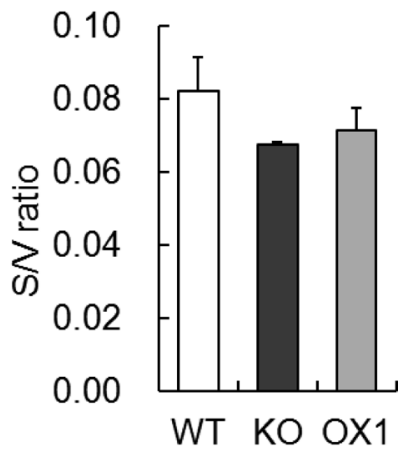

Supplemental Figure S3. Lignin content and composition of ATL54-knock-out and ATL54-overexpressed mutants. (A) Lignin content in organic solvent insoluble residues of mature inflorescence stems determined by the acetyl bromide procedure. Error bars indicate standard errors $(n=3-5)$. (B) Syringaldehyde/vanillin (S/V) ratio obtained by a nitrobenzene oxidation analysis. S/V ratio corresponds to syringyl/guaiacyl ratio in lignin. Error bars indicate standard errors $(n=3-4)$.

A

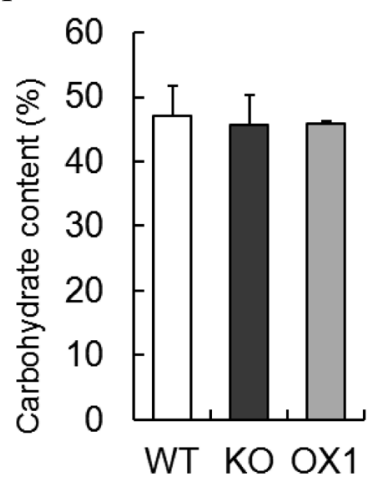

B

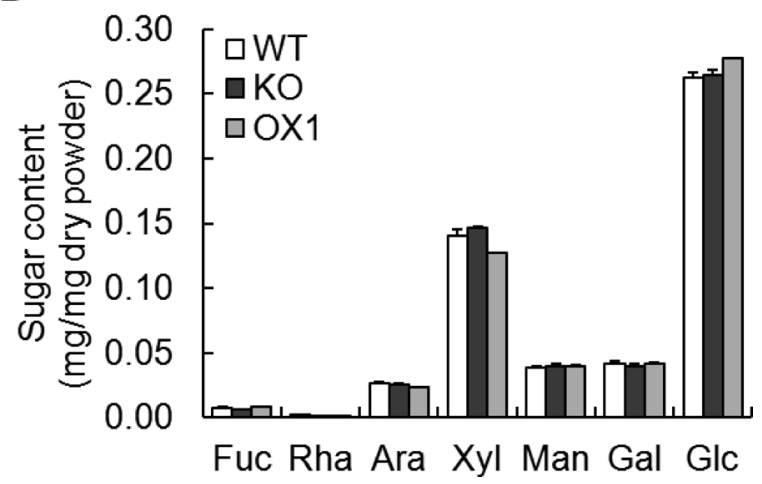

Supplemental Figure S4. Carbohydrate content and neutral sugar composition of ATL54-knock-out and ATL54-overexpressed mutants. (A) Total carbohydrate content in organic solvent insoluble residues of mature inflorescence stems determined by the phenol-sulfuric acid method. Error bars indicate standard errors $(n=3)$. (B) Neutral sugar composition determined as alditol acetates. Fuc, fucose; Rha, rhamnose; Ara, Arabinose; Xyl, xylose; Man, mannose; Gal, galactose; Glc, glucose. Error bars indicate standard errors $(n=3)$. 
Supplemental Table S1. RING-finger protein genes co-expressed with secondary wall-associated genes.

\begin{tabular}{|c|c|c|c|c|c|c|c|c|}
\hline & \multirow{2}{*}{ Gene ID } & \multirow{2}{*}{ Gene alias } & \multicolumn{6}{|c|}{ Co-expressed genes* } \\
\hline & & & $\mathrm{COR} \geqq 0.65$ & $0.6 \leqq \mathrm{COR}<0.65$ & $0.55 \leqq \mathrm{COR}<0.6$ & $0.5 \leqq \mathrm{COR}<0.55$ & $0.45 \leqq \mathrm{COR}<0.5$ & $0.4 \leqq \mathrm{COR}<0.45$ \\
\hline \multirow{10}{*}{$\begin{array}{l}\text { Transcription } \\
\text { factor }\end{array}$} & Atlg32770 & NST3/SND1 & ATL54 & & & & & At2g20650 \\
\hline & At2g 46770 & NST1 & N.A. & N.A. & N.A. & N.A. & N.A. & N.A. \\
\hline & At3g61910 & NST2 & & & & ATL54 & & \\
\hline & Atlg71930 & VND7 & & & & & & \\
\hline & At5g62380 & VND6 & & & & & & \\
\hline & At5g12870 & MYB46 & & & & & ATL54 & At3g47180 \\
\hline & At3g08500 & MYB83 & & & & & & \\
\hline & Atlg62990 & KNAT7 & ATL54 & & ATL11 & & $\begin{array}{l}\text { ATL72, } \\
\text { At5g55970 }\end{array}$ & \\
\hline & Atlg16490 & MYB58 & ATL54 & & & & & \\
\hline & Atlg79180 & MYB63 & & & ATL54 & & & ATL11 \\
\hline \multirow{3}{*}{$\begin{array}{l}\text { Cellulose } \\
\text { synthesis }\end{array}$} & At5g44030 & CesA4 & & & & At2g20650 & ATL54 & \\
\hline & At5g17420 & CesA7 & & & ATL54 & At2g20650 & ATL11 & \\
\hline & At4g18780 & CesA8 & & & & & $\begin{array}{l}\text { ATL54, } \\
\text { At2g20650 }\end{array}$ & \\
\hline \multirow{4}{*}{$\begin{array}{c}\text { Xylan } \\
\text { biosynthesis }\end{array}$} & At2g37090 & $\operatorname{IRX} 9$ & ATL54 & & ATL11 & At2g20650 & & \\
\hline & At4g36890 & $\operatorname{IRX} 14$ & & & & & At2g20650 & \\
\hline & At 4 g33330 & GUX2 & ATL54 & & & ATL11 & At2g20650 & \\
\hline & At2g28110 & FRA8/IRX7 & & ATL72, ATL11 & $\begin{array}{l}\text { At4g23450, } \\
\text { At5g01520, } \\
\text { At3g53410 }\end{array}$ & At5g55970 & & \\
\hline \multirow{10}{*}{$\begin{array}{c}\text { Lignin } \\
\text { biosynthesis }\end{array}$} & At2g37040 & PAL1 & & & & & & \\
\hline & At2g30490 & $\mathrm{C} 4 \mathrm{H}$ & & & & & & \\
\hline & Atlg51680 & $4 C L 1$ & & & & & & \\
\hline & At5g48930 & $H C T$ & & & & & & \\
\hline & At2g40890 & $\mathrm{C} 3 \mathrm{H} 1$ & & & & & & \\
\hline & At4g34050 & CСоАOMT1 & & & & & & At2g20650 \\
\hline & Atlg15950 & CCR1 & & & & & & ATL72 \\
\hline & At4g36220 & F5H1 & & & & & & \\
\hline & At5g54160 & ATOMT1 & & & & & & \\
\hline & At4g34230 & CAD6 & & & At1g63840 & & & \\
\hline
\end{tabular}

Lists of genes co-expressed with secondary wall-associated transcription factor and enzyme genes involved in cellulose, xylan, and lignin biosynthesis were obtained from the ATTED-II ver c4.1 database. Genes annotated as "zinc finger (C3HC4-type RING finger) family protein" are shown. The co-expressed gene list of NST1 was not available in the ATTED-II database N.A., not available. * ATL54, At1g72220; ATL11, Atlg72200; ATL72, At3g10910. 
Supplemental Table S2. Oligonucleotides used in this study.

\begin{tabular}{|c|c|c|}
\hline Name & Sequence & Purpose \\
\hline ENTR-ATL54_f & CACCATGGCGAGGAAGAAGCATCGAAAG & $\begin{array}{l}\text { For subcloning ATL54 cDNA to insert into pH35GS, pH35YG, pH35GY } \\
\text { and pMAL-DC-6myc }\end{array}$ \\
\hline ATL54_r & CAGCGGAAAAACCGAACTCTTG & $\begin{array}{l}\text { For subcloning ATL54 cDNA to insert into pH35GS, pH35YG, pH35GY } \\
\text { and pMAL-DC-6myc }\end{array}$ \\
\hline M13 forward (-20) & GTAAAACGACGGCCAG & For DNA sequencing of pENTR/D-TOPO and pMAL-DC-6myc \\
\hline M13 reverse & CAGGAAACAGCTATGAC & For DNA sequencing of pENTR/D-TOPO \\
\hline p35Sf3 & AGGAAGGTGGCTCCTACAAATGCCATC & For DNA sequencing of $\mathrm{pH} 35 \mathrm{GS}$ and $\mathrm{pH} 35 \mathrm{GY}$ \\
\hline Tnosr1 & TGATAATCATCGCAAGACCGGCAAC & For DNA sequencing of pH35GS, pH35YG and pH35GY \\
\hline malE primer & GGTCGTCAGACTGTCGATGAAGCC & For DNA sequencing of pMAL-DC-6myc \\
\hline ATL54_tag_f & GACTGCTCGAACGGAGTCTGC & For PCR to detect native ATL54 gene and T-DNA-inserted ATL54 gene \\
\hline LBb1 & GCGTGGACCGCTTGCTGCAACT & For PCR to detect T-DNA-inserted ATL54 gene \\
\hline ATL54_tag_r & CCGTAATTGGTTGCTGCCACC & For PCR to detect native ATL54 gene \\
\hline qRT ACT2_f & TCCTCTCCGCTTTGAATTGTCT & For quantitative RT-PCR analysis of the transcript of $A C T 2$ \\
\hline qRT ACT2_r & CTGTCAAGTCGCCGGAGATT & For quantitative RT-PCR analysis of the transcript of ACT2 \\
\hline qRT ATL54_f & CGTCTCTGTTTCAGATCCATCACCG & For quantitative RT-PCR analysis of the transcript of ATL54 \\
\hline qRT ATL54_r & ACTCCCGGAGGATCAGGTTCAC & For quantitative RT-PCR analysis of the transcript of ATL54 \\
\hline qRT CesA8_f & CTTCACGCACGGCTTTGCTATTGT & For quantitative RT-PCR analysis of the transcript of CesA 8 \\
\hline qRT CesA8_r & ATATAGCGGTGCTCGCGACATTGA & For quantitative RT-PCR analysis of the transcript of CesA8 \\
\hline qRT CesA4_f & CCAAACACCATGGCCAGCTTCG & For quantitative RT-PCR analysis of the transcript of CesA4 \\
\hline qRT CesA4_r & ACCGGGTAAACGCACACGTGAC & For quantitative RT-PCR analysis of the transcript of CesA4 \\
\hline qRT CesA7_f & TGAGGGAGGATGGCGGGAAAGA & For quantitative RT-PCR analysis of the transcript of CesA7 \\
\hline qRT CesA7_r & AACTTTCCGCGAGAGTGGCTGC & For quantitative RT-PCR analysis of the transcript of CesA7 \\
\hline qRT 4CL1_f & TGCTGTAGCTGCCGGATTGTT & For quantitative RT-PCR analysis of the transcript of $4 C L 1$ \\
\hline qRT 4CL1_r & TGCCAAACTCGGTCAGGGATA & For quantitative RT-PCR analysis of the transcript of $4 C L 1$ \\
\hline qRT CCoAOMT1_f & TCGTTGATGCTGACAAAGACA & For quantitative RT-PCR analysis of the transcript of CCoAOMT1 \\
\hline qRT CCoAOMT1_r & ACTGATCCGACGGCAGATAG & For quantitative RT-PCR analysis of the transcript of CCoAOMT1 \\
\hline qRT IRX9_f & AATCTTGTGCCGGAAGTCCCTTCA & For quantitative RT-PCR analysis of the transcript of IRX 9 \\
\hline qRT IRX9_r & GTGGTAGTAGAAGGGCCTGTTTGT & For quantitative RT-PCR analysis of the transcript of $I R X 9$ \\
\hline qRT IRX14_f & ACCACGACGGTGTTGCCTTG & For quantitative RT-PCR analysis of the transcript of $I R X 14$ \\
\hline qRT IRX14_r & GCGCTGATAGCAAATTCCCTCCCG & For quantitative RT-PCR analysis of the transcript of $I R X 14$ \\
\hline qRT GUX1_f & ATTTGCGGCCTCTGCTTGCC & For quantitative RT-PCR analysis of the transcript of GUX1 \\
\hline qRT GUX1_r & CCTTGGGATGAAGCCGTGGTTATGT & For quantitative RT-PCR analysis of the transcript of GUX1 \\
\hline qRT GUX2_f & GCGTTTGGTGTTTGTCTGAAGGAGG & For quantitative RT-PCR analysis of the transcript of GUX2 \\
\hline qRT GUX2_r & TCGCCCTGAGGTGGTTAGGT & For quantitative RT-PCR analysis of the transcript of GUX2 \\
\hline qRT XCP1_f & TGTGACAATCAGCGGCTACGAAGA & For quantitative RT-PCR analysis of the transcript of XCP1 \\
\hline qRT XCP1_r & ATGAACCATATCCAACCTCTGCCA & For quantitative RT-PCR analysis of the transcript of $X C P 1$ \\
\hline
\end{tabular}

